\title{
Effect of Deep Brain Stimulation on Quality of Life in Patients with Parkinson's Disease
}

\author{
Parkinsonlu Hastalarda Derin Beyin Stimülasyonunun Yaşam Kalitesine Etkisi
}

\author{
(1) Esra Doğru Hüzmeli ${ }^{1}$, (1) Atilla Yılmaz ${ }^{2}$ \\ ${ }^{1}$ Mustafa Kemal University School of Physical Therapy and Rehabilitation, Department of Neurological Rehabilitation, Hatay, Turkey \\ 2Mustafa Kemal University Tayfur Ata Sokmen Medicine Faculty, Department of Neurosurgery, Hatay, Turkey
}

\begin{abstract}
Objective: To investigate the effect of deep brain stimulation (DBS) on quality of life (QOL) in patients with Parkinson's disease (PD).

Materials and Methods: The study included 19 patients with idiopathic PD who underwent DBS surgery at Mustafa Kemal University Faculty of Medicine, Neurosurgery Department. Patient characteristics, duration of disease, and the dominant hand of each patient were noted from the patients' clinical records. The QOL of the patients was assessed using the RAND 36-Item Health Survey 1.0 (RAND-36) and the symptoms of PD were evaluated using the Unified PD Rating Scale (UPDRS), which was administered preoperatively when the medication was on (within one week prior to surgery) and postoperatively when the medication and stimulation were on (2 months after the surgery; range, 55-65 days).

Results: The study included 19 patients with PD, comprising $12(63.2 \%)$ men and 7 (36.8\%) women with a mean age of 52.07 \pm 9.89 (range, 38-72) years. The mean duration of disease was $6.60 \pm 5.92$ years. A sex-based analysis of the RAND-36 scores indicated that there was a significant difference between the pre- and postoperative scores of the female patients for bodily pain $(p=0.028)$ and between the pre- and postoperative scores of the male patients for emotional well-being $(\mathrm{p}=0.032)$. However, no significant difference was found between the pre- and postoperative scores of other subcategories in both sexes ( $p>0.05)$. On the other hand, postoperative UPDRS scores decreased compared with preoperative scores in all patients.

Conclusion: This study is the first region-wide prospective study to investigate the effects of subthalamic nucleus (STN)-DBS in patients with PD for our region. The results indicated that STN-DBS surgery had a positive effect on the QOL in patients with PD.
\end{abstract}

Keywords: Deep brain stimulation, quality of life, Parkinson's disease

Öz

Amaç: Çalışma, derin beyin stimülasyonunun (DBS) Parkinson hastalı̆̆ı (PH) tanılı bireylerde yaşam kalitesine etkisini bulmayı amaçlamaktadır.

Gereç ve Yöntem: Çalışmaya Mustafa Kemal Üniversitesi Tıp Fakültesi, Beyin ve Sinir Cerrahisi Anabilim Dalı'nda ilaca dirençli idiyopatik PH tanısıyla subtalamik nükleus bölgesine DBS cerrahisi uygulanmış 19 birey dahil edildi. Demografik bilgiler hasta kayıtlarından toplandı. Değerlendirme cerrahi öncesi (cerrahi öncesi 1 hafta içinde) ve cerrahiden 2 ay sonra (55-65 gün arası) olmak üzere iki kez yapıldı. Değerlendirmede, yaşam kalitesi RAND 36-Item Health Survey 1.0 (RAND-36) ile PH'ye özgü semptomlar ise Birleşik PH Derecelendirme Ölçeği ile değerlendirildi.

Bulgular: Çalışmaya dahil edilen 12'si erkek 7'si kadın 19 hastanın yaş ortalaması 52,07 yıl (38-72 yıl arasında) ortalama hastalık süresi ise 6,60 yıldı. Kadın olguların RAND-36 değerlendirmesinin vücut ağrısı parametresinin medyan sonuçları cerrahi öncesi 33 (minimum-maksimum=0-80), cerrahi sonrası ise 90 (minimum-maksimum=23-100) olduğu ve aradaki farkın anlamlı olduğu $(\mathrm{p}=0,028)$. Erkek olguların duygu durum iyilik hali parametrelerinin medyan sonuçlarının ise cerrahi öncesi 72 iken (minimum-maksimum=48-96), cerrahi sonrası 64 (minimum-maksimum=48-88) olduğu ve aradaki farkın yine anlamlı olduğu tespit edildi $(\mathrm{p}=0,032)$. Her iki cinsiyet grubunun ameliyat öncesi ve sonrası diğer de ğerlendirme parametrelerinin sonuçlarının arasında ise anlamlı bir fark olmadığı tespit edildi $(\mathrm{p}>0,05)$. Bununla birlikte Birleşik PH Derecelendirme Ölçeği motor parametreleri ortalamasında cerrahi sonrası düşüşs saptanmıştır. Sonuç: Çalışmamız; bölgemizde STN-DBS cerrahisinin PH üzerindeki etkisinin araştırıldı̆̆ı ilk kapsamlı çalışma olup, elde ettiğimiz sonuçlara göre STN-DBS cerrahisinin özellikle kadın olgularda yaşam kalitesi üzerinde istatistiksel olarak anlamlı pozitif etkiye sebep olduğu tespit edilmiştir.

Anahtar Kelimeler: Derin beyin stimülasyonu, yaşam kalitesi, Parkinson hastalığ

Address for Correspondence/Yazışma Adresi: Atilla Yılmaz MD, Mustafa Kemal University Faculty of Tayfur Ata Sokmen Medicine, Department of Neurosurgery, Hatay, Turkey

Phone: +90 3262291000 E-mail: atillayilmaz@hotmail.com ORCID ID: orcid.org/0000-0002-1081-3545

Received/Geliş Tarihi: 20.12.2017 Accepted/Kabul Tarihi: 07.03.2018

${ }^{\circledR}$ Copyright 2018 by Turkish Neurological Society

Turkish Journal of Neurology published by Galenos Publishing House. 


\section{Introduction}

Deep brain stimulation (DBS) surgery is a neurosurgical procedure commonly used in the treatment of Parkinson's disease (PD). However, DBS was not considered a treatment method until the early 1990s, rather an experimental method (1). To date, a large number of patients have been treated with DBS since the administration of the first procedure. Numerous studies have shown that DBS has clinical effects on motor symptoms. DBS is primarily used for the treatment of neurologic and psychiatric disorders and is mostly preferred for patients with PD who experience troublesome levodopa-related complications and patients with severe essential tremor and dystonia $(2,3)$.

Patients with PD typically experience shaking, rigidity, slowness of movement, difficulty walking, and gait problems in the early stage of the disease as opposed to cognitive and behavioral problems such as sleep and emotional problems, depression, severe fatigue, and pain in the late stage. These late-stage conditions mainly arise from the motor problems occurring in the early stage. Importantly, these motor and psychological problems decrease the quality of life (QOL) of the patients $(4,5)$, which is a major concern in the treatment of PD.

Oyama et al. (6) retrospectively evaluated the effect of DBS on QOL and found that QOL was higher in the DBS group compared with the non-DBS group, although this finding was considered to be speculative in the absence of pre-surgical data for comparison. Volkmann et al. (7) examined the long-term effects of DBS using a QOL scale known as the Sickness Impact Profile (SIP). The study revealed that DBS significantly improved the sub-categories of SIP including total, physical, and psychosocial parameters from baseline to 6 months. However, although significant improvements occurred in some categories including body care/movement, eating, recreation/pastimes, social interaction, and mobility, the total, physical, and psychosocial SIP scores decreased significantly, and also most of the SIP sub-category scores dropped to their baseline values after 3 years (7). As indicated by these studies, the effect of DBS on QOL remains inconclusive. To our knowledge, there have been no studies in the literature investigating the effect of DBS on each sex separately. Accordingly, the present study aimed to investigate the effect of DBS on QOL in patients with PD and to examine the sex-based effects of DBS.

\section{Materials and Methods}

The study included 24 patients with idiopathic PD who underwent DBS surgery for movement disorders caused by PD at Mustafa Kemal University Medical Faculty, Neurosurgery Department between 2015 and 2017. Of these, 3 patients were excluded due to communication problems and 2 others due to psychiatric problems. As a result, 19 patients were eligible to be included in the study.

The inclusion criteria were idiopathic PD responsive to L-dopa treatment, aged between 35 and 75 years, having received bilateral subthalamic nucleus (STN) DBS surgery for at least two months to ensure stable stimulation parameters and mentally normal patients who could understand and complete the questionnaire.

Exclusion criteria were aged $>75$ years, the presence of secondary parkinsonism, abnormal brain magnetic resonance imaging (MRI) findings, severe dementia, and history of a serious disease. Patient characteristics, duration of disease, and the dominant hand of each patient were noted from the patients' clinical records. Ethical approval was obtained from Mustafa Kemal University Faculty of Medicine Ethics Committee (date: 05.10.2017) and written informed consent was received from each participant. The study protocol was performed in accordance with the Declaration of Helsinki.

The QOL of the patients was assessed using the RAND 36Item Health Survey 1.0 (RAND-36). This survey was preferred because it is frequently used in clinical practice. This survey embodies eight subcategories including physical functioning, bodily pain, role limitations due to physical health problems, role limitations due to personal or emotional problems, emotional well-being, social functioning, energy/fatigue, and general health perceptions. A high score defines a more favorable health state, and each item is scored on a $0-100$ scale. The survey includes the same items as those in the short form (SF)-36 but the recommended scoring algorithm is different from that of the SF-36. Moreover, the RAND-36 survey is an exact replica of the SF-36, which is a valid and reliable scale commonly used in Turkey $(8,9,10)$.

The symptoms of PD were evaluated using the Unified PD Rating Scale (UPDRS), which was administered preoperatively when the medication was on (within one week prior to surgery) and postoperatively when the medication and stimulation were on (2 months after the surgery; range, 55-65 days). UPDRS is the gold standard reference scale, which was developed to examine the typical PD symptoms. In addition, the UPDRS has been the most widely used scale to assess impairment and disability in PD, in which a higher score indicates a poor health status for the patient. The scale itself has four components: Part 1, Mentation, Behavior, and Mood; Part 2, Activities of Daily Living; Part 3, Motor; Part 4 , Complications $(11,12)$. Of these parts, we examined only Part 3 in our patients.

\section{Surgical Procedure}

First, high-resolution T1 and T2-weighted MRI were obtained within 1 week prior to the procedure using a 1.5 Tesla MRI scanner (Philips, Ingenia). On the day of surgery, a stereotactic frame (Radionics ${ }^{\circledR} \mathrm{CRW}^{\mathrm{TM}}$ ) was mounted under local anesthesia, and then the patients were sent for computed tomography (CT) scan, and the obtained images were fused with the previously obtained MRI using preoperative stereotactic planning software (NeuroSight ${ }^{\mathrm{TM}}$ Arc). After identifying the anterior and posterior commissures, the dorsolateral part of the STN was targeted, which was confirmed using stereotactic atlases. Subsequently, the X, Y, and $\mathrm{Z}$ coordinates were calculated and then the surgical procedure was initiated.

The surgical procedure was conducted in two parts. In the first part, eight contact leads (Vercise ${ }^{\mathrm{TM}}$ Boston Scientific) were implanted in both sides of the targeted area under local anesthesia. Before the placement, micro electro recording (NeuroNav ${ }^{\mathrm{TM}}$ AlphaOmega) was performed using a maximum of three electrodes in each patient in order to select the best effective area. After the implantation of the eight contact leads, macro stimulation was performed to evaluate the effect of the stimulation and to exclude adverse effects. Subsequently, after securing the leads and the wound closure, the second part of the procedure was started. 
In this part, a neurostimulator (Vercise ${ }^{\mathrm{TM}}$ Boston Scientific) was placed in the subclavicular region under general anesthesia and was connected to the electrodes by the extension cables. The second part of the surgery was performed either immediately or within a maximum period of 1 week after the first part, depending on the clinical condition of the patients or the preference of the surgical team. After the second part of the procedure, a repeat CT scan was performed, and the images were fused with preoperative MRI images using GUIDE ${ }^{\mathrm{TM}}$ DBS software in order to evaluate the exact position of the electrodes.

Stimulation was initiated at least two weeks after the procedure and thresholds were determined for any stimulation-induced adverse effects in all contacts. The final stimulation parameters were determined based on the results of the adverse effects and on the optimal antiparkinsonian effects. The adjustments of the stimulation and the medication were made depending on the long-term effects of the procedure.

\section{Statistical Analysis}

Statistical analyses were performed using the IBM SPSS Statistics for Windows, Version 22.0. (Armonk, NY: IBM Corp.) statistical software. Descriptive statistics were expressed as mean \pm standard deviation for continuous variables and as minimummaximum for categorical variables. Normal distribution of the data was tested using the Shapiro-Wilk test. Comparison of preand post-operative differences was achieved using the Wilcoxon signed-rank test. A p value of $<0.05$ was considered significant.

\section{Results}

The study included 19 patients with PD, comprising 12 $(63.2 \%)$ men and $7(36.8 \%)$ women with a mean age of $52.07 \pm 9.89$ (range, 38-72) years. The mean duration of disease was $6.60 \pm 5.92$ years. Postoperative UPDRS scores decreased compared with preoperative scores in all patients (Table 1 ).

Table 2 presents the pre- and post-operative median scores for each subcategory in the RAND-36 survey. Although the postoperative scores increased compared with preoperative scores, no significant difference was found between the pre- and postoperative scores (Table 2).

A sex-based analysis on the RAND-36 scores indicated that there was a significant difference between the pre-and postoperative scores of the female patients for bodily pain $(\mathrm{p}=0.028)$ and between the pre- and postoperative scores of the male patients for emotional well-being $(\mathrm{p}=0.032)$. However, no significant difference was found between the pre- and postoperative scores of other subcategories in both sexes ( $\mathrm{p}>0.05)$ (Tables 3, 4).

Table 1. Demographic characteristic of the patients

\section{Variable}

Mean age (year; $\overline{\mathrm{X}} \pm \mathrm{SD}$ )

Male (year; $\overline{\mathrm{X}} \pm \mathrm{SD}$ )

Female (year; $\overline{\mathrm{X}} \pm \mathrm{SD}$ )

Sex

Duration of disease (year; $\overline{\mathrm{X}} \pm \mathrm{SD}$ )

Dominant hand

Mean UPDRS score (mean \pm SD; pre-op/post-op)

UPDRS score-female patients (mean \pm SD; pre-op [on medication]/post-op [on medication, on stimulation]) UPDRS score-male patients (mean \pm SD; pre-op [on medication]/post-op [on medication, on stimulation])

$\overline{\mathrm{X}}$ Mean, SD: Standard deviation

\section{Table 2. Pre- and post-operative median scores for the subcategories in the RAND-36 survey}

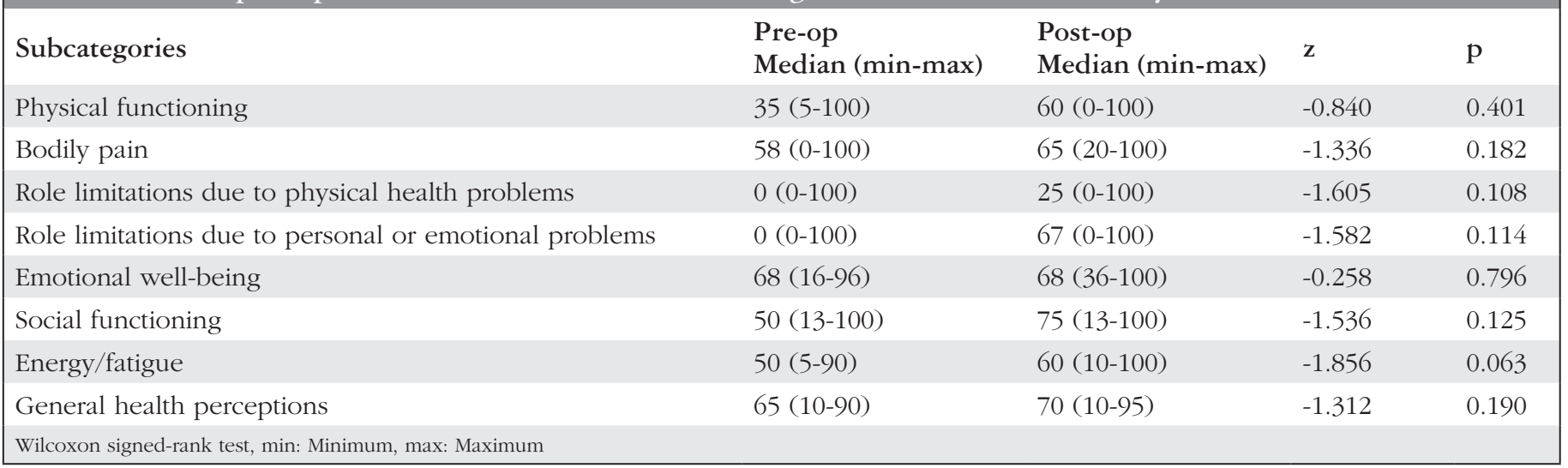


Table 3. Pre- and post-operative RAND-36 scores for female patients

\begin{tabular}{|llll} 
Subcategories & $\begin{array}{l}\text { Pre-op } \\
\text { Median (min-max) }\end{array}$ & $\begin{array}{l}\text { Post-op } \\
\text { Median (min-max) }\end{array}$ & $\mathbf{z}$ \\
Physical functioning & $30(5-60)$ & $60(0-95)$ & -1.577 \\
Bodily pain & $33(0-80)$ & $90(23-100)$ & -2.201 \\
Role limitations due to physical health problems & $0(0-100)$ & $25(0-100)$ & -1.242 \\
$\begin{array}{l}\text { Role limitations due to personal or emotional } \\
\text { problems }\end{array}$ & $0(0-25)$ & $0(0-100)$ & -1.089 \\
Emotional well-being & $68(16-80)$ & $76(36-100)$ & 0.214 \\
Social functioning & $25(13-38)$ & $75(13-88)$ & -1.191 \\
Energy/fatigue & $40(15-80)$ & $60(10-100)$ & -1.897 \\
General health perceptions & $55(10-80)$ & $65(10-90)$ & -1.581 \\
Wilcoxon signed-rank test, ${ }^{p}$ p $<0.05$, min: Minimum, max: Maximum & & & 0.320 \\
\hline
\end{tabular}

Table 4. Pre- and post-operative RAND-36 scores for male patients

\begin{tabular}{|c|c|c|c|c|}
\hline Subcategories & $\begin{array}{l}\text { Pre-op } \\
\text { Median (min-max) }\end{array}$ & $\begin{array}{l}\text { Post-op } \\
\text { Median (min-max) }\end{array}$ & $\mathrm{z}$ & $\mathrm{p}$ \\
\hline Physical functioning & $55(10-100)$ & $60(0-100)$ & -0.0338 & 0.735 \\
\hline Bodily pain & $60.5(10-100)$ & $61.5(20-100)$ & -0.356 & 0.416 \\
\hline Role limitations due to physical health problems & $0(0-100)$ & $37.5(0-100)$ & -0.813 & 0.416 \\
\hline Role limitations due to personal or emotional problems & $0(0-25)$ & $67(0-100)$ & -1.179 & 0.238 \\
\hline Emotional well-being & $72(48-96)$ & $64(48-88)$ & -1.201 & $0.032^{*}$ \\
\hline Social functioning & $56.5(13-100)$ & $69(13-100)$ & -0.315 & 0.735 \\
\hline Energy/fatigue & $60(5-90)$ & $62.5(15-100)$ & -1.120 & 0.263 \\
\hline General health perceptions & $67.5(15-90)$ & $75(30-95)$ & -1.722 & 0.238 \\
\hline Wilcoxon signed-rank test, ${ }^{*} \mathrm{p}<0.05$, min: Minimum, max: Maximum & & & & \\
\hline
\end{tabular}

\section{Discussion}

This study aimed to evaluate the effect of DBS on QOL in patients with PD. The results indicated that DBS had positive effects on QOL in both male and female patients.

In our study, preoperative UPDRS part 3 scores were lower in men (13.58) compared with female patients (23.71) and these scores decreased to 4.58 in men and 9.86 points in women postoperatively. These findings indicated that the rate of motor recovery in women was greater than that of men, implicating that the probability of motor recovery is greater in patients with poor health status compared with patients that have a relatively better health status preoperatively.

The effect of DBS on QOL is associated with the motor scores of the patients. Accordingly, the presence of postural instability, high body mass index and worse baseline motor scores are key predictors of poorer functional and QOL outcomes after DBS (13). On the other hand, QOL is also related to functional independence (14). Floden et al. (15) examined the disease, treatment, cognitive, and psychological factors associated with QOL before and after surgery by assessing the strength of these factors in the prediction of QOL outcomes. The study showed that $51 \%$ of their patients reported clinically significant improvements in QOL, whereas $47 \%$ reported stable QOL and 2\% worsened (13). Appleman et al. (16) reported that individuals with PD who experienced rigidity, gait and balance impairments at diagnosis reported a significantly worse QOL than individuals who experienced tremor as their initial symptom. Lyons and Pahwa (17). found that the significant improvements in QOL following DBS were strongly correlated with improvements in motor function, primarily with regards to bradykinesia. In our study, the average UPDRS score for female patients decreased from 23.71 to 9.86 in only 2 months, which indicates a remarkable improvement in the QOL of female patients. In contrast, no remarkable improvement was observed in the QOL of male patients because they had a relatively lower decrease rate between the pre- and post-operative UPDRS scores and their preoperative scores were already high compared with those of female patients. This finding could be ascribed to the fact that the male patients had greater expectations from the DBS surgery and thus were less satisfied by the surgery compared with the female patients.

Tamas et al. (18) examined the effect of STN stimulation on distal and proximal upper limb movements in patients with PD and found that STN stimulation improved the speed, amplitude, and rhythm of upper limb movements. However, the assessments were performed within an average period of 2.1 years after the surgery (18). We consider that this period is long enough to notice 
the effect of DBS on motor recovery. Accordingly, because we performed the assessments at postoperative month 2, we consider that this time period is not enough to evaluate the actual outcomes of the surgery and thus the evaluation should be repeated at later stages throughout the follow-up period.

Chan et al. (19) also conducted a study to evaluate the effects of STN-DBS in patients with PD at post-operative first and second years and found that the patients had satisfactory outcomes. Moreover, the results showed that the reduction in the UPDRS motor scores, as well as the awake "off"-time and the daily levodopa dosage, were the major predictors of overall improvement in the 39-item PD questionnaire. In our patients, the postoperative assessment was performed at a relatively earlier period compared with the time periods reported in the literature. Therefore, we are planning to re-examine our patients in the first year to better evaluate the outcomes in our patients.

Jiang et al. (20) conducted a meta-analysis that reviewed 39 studies published between 1993 and 2014. The analysis indicated that DBS led to significant improvements in QOL as well as motor symptoms in patients with PD after surgery. Moreover, a significant improvement was achieved in QOL following DBS compared with no improvement after medical therapy. Similarly, Chou et al. (21) examined the effect of DBS in both motor and non-motor symptoms after bilateral STN-DBS for PD. The authors compared preoperative (baseline) and postoperative scores (approximately six months following the initial programming visit) in 20 patients and revealed that both motor and non-motor symptoms improved with bilateral STN stimulation 6 months after the stimulation. However, it is worth noting that these studies mainly focused on the motor and non-motor symptoms of PD and most ignored the QOL of the patients. We consider that QOL is an important indicator of physical and mental wellbeing and thus should be considered by physicians during the assessment of patients with PD.

\section{Study Limitation}

The main limitation of our study was that there was no control group and the sample size was relatively small. Therefore, further studies with larger patient series are needed to investigate STNDBS surgery on QOL. Secondly, the postoperative assessment was performed at an early stage compared with the literature. Finally, the patients' socioeconomic status, stage of the disease, and the family's support could affect the results too.

\section{Conclusion}

Our results indicated that the STN-DBS surgery had a positive effect on QOL in patients with PD.

Ethics

Ethics Committee Approval: Ethical approval was obtained from Mustafa Kemal University Faculty of Medicine Ethics Committee (date: 05.10.2017). The study protocol was performed in accordance with the Declaration of Helsinki.

Informed Consent: Written informed consent was received from each participant.

Peer-review: Externally peer-reviewed.

\section{Authorship Contributions}

Concept: E.D.H., A.Y., Design: E.D.H., A.Y., Data Collection or Processing: E.D.H., A.Y., Analysis or Interpretation: E.D.H., A.Y., Literature Search: E.D.H., A.Y., Writing: E.D.H., A.Y.
Conflict of Interest: Dr. Yilmaz has disclosures with Boston Scientific and Medtronic in terms of proctorship.

Financial Disclosure: The authors declared that this study received no financial support.

\section{References}

1. Benabid AL, Pollak P, Gervason C, et al. Long-term suppression of tremor by chronic stimulation of the ventral intermediate thalamic nucleus. Lancet 1991;337:403-406.

2. Toft M. Deep Brain Stimulation in Parkinson's Disease - Impact on Quality of Life. European Neurological Review 2012;7(Suppl 1):27-30.

3. Diamond A, Jankovic J. The effect of deep brain stimulation on quality of life in movement disorders. J Neurol Neurosurg Psychiatry 2005;76:1188-1193.

4. Opara J. Current possibilities of evaluation of quality of life in Parkinson disease. Neurol Neurochir Pol 2003;37(Suppl 5):241-250.

5. Opara JA, Brola W, Leonardi M, Blaszczyk B. Quality of life in Parkinson's Disease. J Med Life 2012;5:375-381.

6. Oyama G, Okun MS, Schmidt P, et al. Deep Brain Stimulation May Improve Quality of Life in People With Parkinson's Disease Without Affecting Caregiver Burden. Neuromodulation 2014;17:126-132.

7. Volkmann J, Albanese A, Kulisevsky J, et al. Long-term effects of pallidal or subthalamic deep brain stimulation on quality of life in Parkinson's disease. Mov Disord 2009;24:1154-1161.

8. Ware JE Jr, Sherbourne CD. The MOS 36-Item Short-Form Health Survey (SF-36): I. Conceptual framework and item selection. Med Care 1999;30:473483.

9. Hays RD, Sherbourne CD, Mazel RM. The RAND 36-Item Health Survey 1.0. Health Econ 1993;2:217-227.

10. Kocyigit H, Aydemir O, Fisek G, Ölmez N, Memiş A. Kısa Form-36 (SF36)'nın Türkçe Versiyonunun Güvenilirliği ve Geçerliliği. İlac ve Tedavi Dergisi 1999;12:102-106.

11. Fahn S, Elton RL. UPDRS program members. Unified Parkinsons Disease Rating Scale. In: Fahn S, Marsden CD, Goldstein M, Calne DB, (eds). Recent developments in Parkinson's disease. Florham Park, NJ: Macmillan HealthcareInformation, 1987:153-163.

12. http://www.theracycle.com/pd/parkinsons-updrs-scale.aspx. Accessed date: 01.12.2017.

13. Abboud H, Genc G, Thompson NR, et al. Predictors of Functional and Quality of Life Outcomes following Deep Brain Stimulation Surgery in Parkinson's Disease Patients: Disease, Patient, and Surgical Factors. Parkinsons Dis 2017;2017:5609163.

14. Luz CL, Moura MCDS, Becker KK, Teixeira RAA, Voos MC, Hasue RH. The relationship between motor function, cognition, independence and quality of life in myelomeningocele patients. Arq Neuropsiquiatr 2017;75:509-514.

15. Floden D, Cooper SE, Griffith SD, Machado AG. Predicting quality of life outcomes after subthalamic nucleus deep brain stimulation. Neurology 2014;83:1627-1633.

16. Appleman ER, Stavitsky K, Cronin-Golomb A. Relation of Subjective Quality of Life to Motor Symptom Profile in Parkinson's Disease. Parkinsons Dis 2011;2011:472830.

17. Lyons KE, Pahwa R. Long-term benefits in quality of life provided by bilateral subthalamic stimulation in patients with Parkinson disease. J Neurosurg 2005;103:252-255.

18. Tamas G, Kelemen A, Radics P, et al. Effect of subthalamic stimulation on distal and proximal upper limb movements in Parkinson's disease. Brain Res 2016;1648:438-444

19. Chan DT, Zhu CX, Lau CK, et al. Subthalamic Nucleus Deep Brain Stimulation for Parkinson Disease in Hong Kong: A Prospective TerritoryWide 2-Year Follow-Up Study. World Neurosurg 2016;93:229-236.

20. Jiang JL, Tsai ST, Chen SY. Effects of subthalamic nucleus deep brain stimulation on quality of life and motor and depressive symptoms in Parkinson's disease. Tzu Chi Medical Journal 2015;27:145-154.

21. Chou KL, Taylor JL, Patil PG. The MDS-UPDRS tracks motor and nonmotor improvement due to subthalamic nucleus deep brain stimulation in Parkinson disease. Parkinsonism Relat Disord 2013;19:966-969. 